\title{
VCL wt Allele
}

National Cancer Institute

\section{Source}

National Cancer Institute. VCL wt Allele. NCI Thesaurus. Code C52335.

Human VCL wild-type allele is located within 10q22.1-q23 and is approximately $122 \mathrm{~kb}$ in length. This allele, which encodes vinculin protein, is involved in the mediation of cellular adhesion, morphology and motility. 